\title{
Combined Results of New Surgery Approach and Hormone Therapy with Massive Diffuse Forms of Adenomyosis
}

\author{
Vitaly Tskhay*, Grebennikova E and Mikaela G \\ Department of Perinatology, Obstetrics and Gynecology, Krasnoyarsk State Medical University, Russia
}

Submission: May 08, 2018; Published: June 21, 2018

*Corresponding author: Tskhay V, Department of Perinatology, Obstetrics and Gynecology, Krasnoyarsk State Medical University named after prof. V.F. Voino-Yasenetsky, Krasnoyarsk, Russia, Tel: +79232872134; Email: tchai@yandex.ru

Abstract

The advised treatment for severe adenomyosis is hysterectomy, but the patients wishing to preserve their uterus were operated with a novel conservative surgery, called adenomyomectomy. The history of this new surgery approach dates back to 2011 when Japanese Professor Hisao Osada worked it out and applied this new method of surgery for his patients. Adenomyomectomy, in this method, suggests radically excised adenomyotic tissues and reconstructed uterine wall by a triple-flap method, without overlapping suture lines, to prevent uterine rupture in subsequent pregnancies. This is a prospective case series followed for 6 years from October 2012 to January 2018 of 26 women with massive diffuse adenomyosis verified histologically and diagnosed with ultrasound. 18 women of 26 wished to conceive; 3 patients became spontaneous pregnant and delivered healthy babies. There were no cases of uterine rupture. Adenomyosis symptoms did not recur in all 26 cases. Thus, our experience of intraoperative radical resection of adenomyotic tissues suggests that this technique may be a surgery of the patient's choice, especially for women of reproductive age with diffuse adenomyosis, we use it for those aging ones who wish to preserve the uterus.

Keywords: Hormone therapy; Adenomyosis; Hysterectomy; Adenomyomectomy; Adenomyotic tissues; Uterine wall; Triple-flap method; Infertility; Conservative surgery; Diffuse adenomyosis; Uterine adenomyosis; Hyperplastic myometrium; Subfertility; Algomenorrhea; Dyspareunia; Gonadoliberin; Hormonal contraceptives; Extraperitonealization; Hemostasis; Uterine cavity; Epigenetic therapy; Gonadotropin

Abbreviations: COCs: Combined Hormonal Contraceptives

\section{Introduction}

Uterine adenomyosis is a gynecologic condition whose diagnosis and clinical significance remains somewhat enig $\neg$ matic [1-3]. Adenomyosis is defined as a benign invasion of the endome $\neg$ trium into the myometrium, producing a diffusely enlarged uterus, which microscopically exhibits ectopic, nonneoplastic endometrial glands and stroma surrounded by the hypertrophic and hyperplastic myometrium [4]. The role of surgery in managing extensive uterine adenomyosis and subfertility is still highly controversial, partly because the diagnosis of adenomyosis has always been retro $\neg$ spective, and adenomyosis often involves the whole uterus diffusely, with difficulty separating normal myometrial tissue from myometrial tissue invaded by adenomyosis [5-9]. In 2011 a Japanese professor Hisao Osada published an observation of conducted organ-preserving surgical treatment of patients with adenomyosis in the period from 1998 to 2008 [10]. In July 2012, for the first time, we performed the operation of adenomyomectomy with the reconstruction of the uterus wall by three-flap method proposed by Hisao Osada.

\section{Objective}

The aim of our study was to assess the long-term efficacy of conservative surgery by the method of H. Osada combined with hormonal therapy for the patients with massive diffuse adenomyosis.

\section{Materials and Methods}

This is a prospective case series followed from October 2012 to March 2018 of 26 women with severe adenomyosis. The average age of patients amounted to $35.3 \pm 7.2$ (22 to 47) years. However 8 patients were not interested in reproductive functions, but insisted on having conservative surgery. All patients $(100 \%)$ complained about chronic abnormal uterine bleeding, 22 (84.6\%)-algomenorrhea, 16 (61.5\%)- dyspareunia, $19(73.07 \%)$ patients had chronic hemorrhagic anemia of varying severity. 18 (69.2\%) patients had history of infertility. In all patients records there were repeated but unsuccessful courses of adenomyosis treatment with hormonal therapy (progestin, agonists of gonadoliberin, combined hormonal contraceptives). 


\section{Global Journal of Reproductive Medicine}

Results

A total of 26 women with pathologically proven diffuse adenomyosis underwent new surgical method of adenomyomectomy, where adenomyotic tissues were radically excised and the uterine wall was reconstructed by a triple-flap method (named after H. Osada) and later had a subsequent 12-month course of hormonal treatment; were evaluated semiannually during a follow-up period of at least 5 years. This laparotomy technique involves:

I. Extra peritonealization of the uterus and rubber tourniquet placement for hemostasis;

II. Bisection of the uterus in the midline and in the sagittal plane with a scalpel until the uterine cavity is reached (Figure1 \& 2);

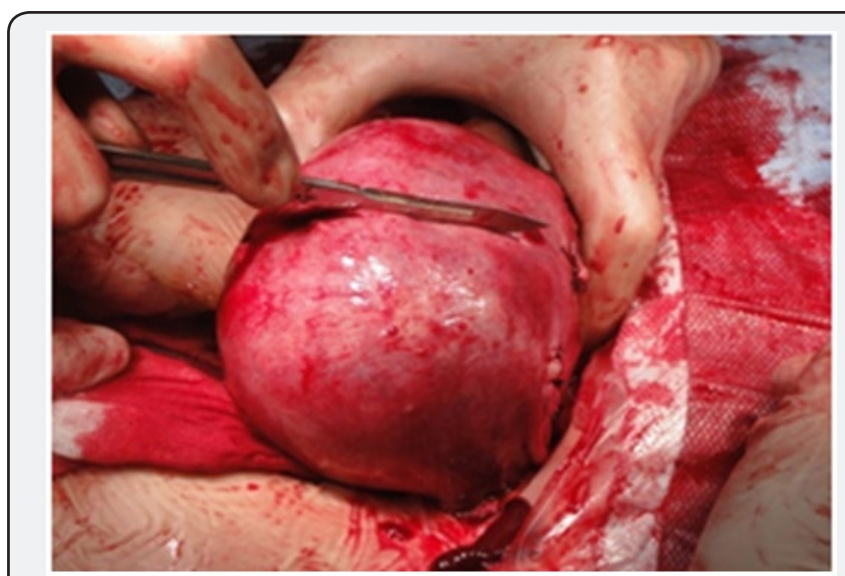

Figure 1: Bisection of the uterus in the midline. The size of the uterus equals about 13 weeks of gestation.

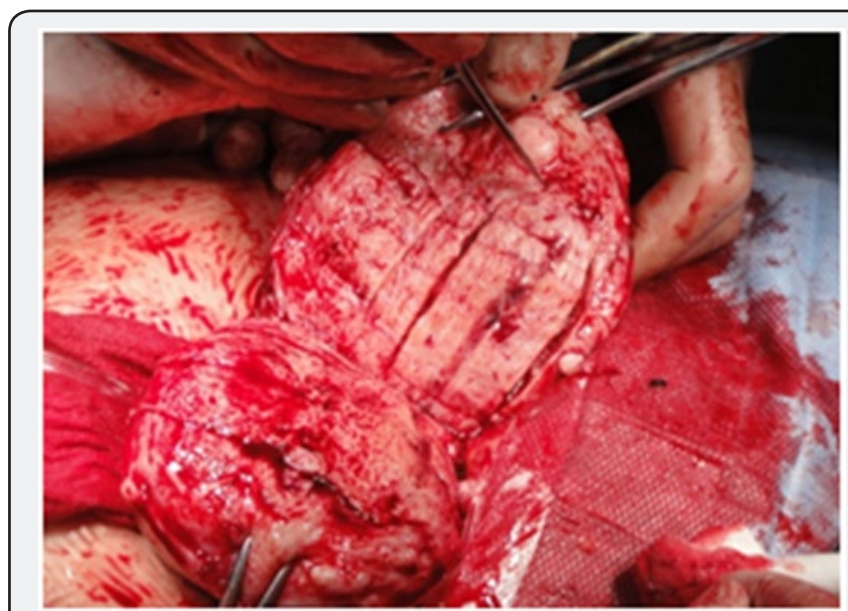

Figure 2: Bisection of the uterus in the midline and in the sagittal plane with a scalpel until the uterine cavity is reached.

III. Opening of the endometrial cavity to permit the introduction of the index finger to guide during excision of adenomyotic tissues;

IV. The use of Martin forceps to grasp adenomyotic tissues and to excise them from surrounding myometrium, leaving a myometrial thickness of $1 \mathrm{~cm}$ from serosa above and endometrium below (Figure 3).

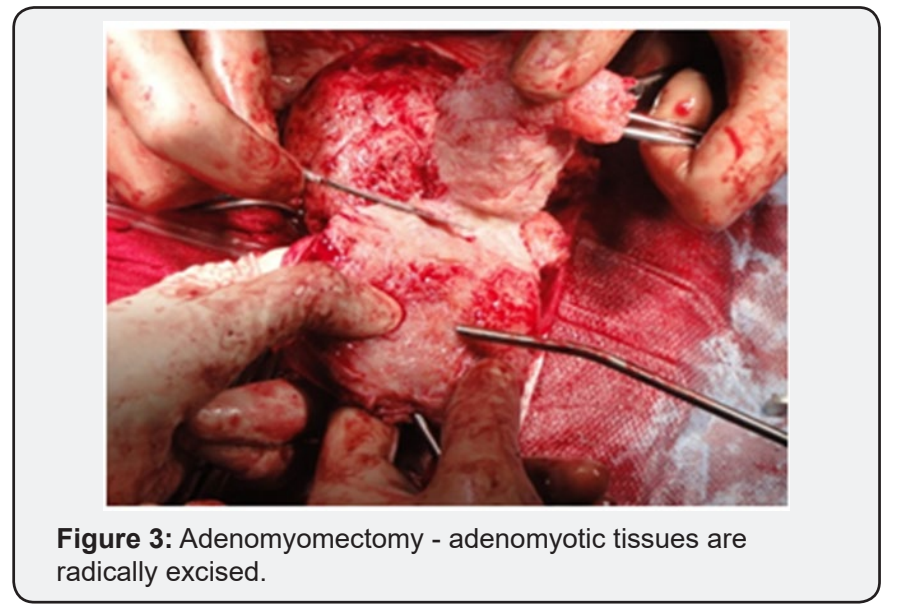

V. Closure of the endometrium with 3-0 Vicryl; and

VI. Closure of the flaps of the uterine wall approximating the myometrium and serosa of one side of the bisected uterus in the anteroposterior plane with interrupted 2-0 Vicryl, while the contralateral side of the uterine wall is brought over the reconstructed first side in such a way as to cover it (Figure 4 \& 5) $[9,10]$.

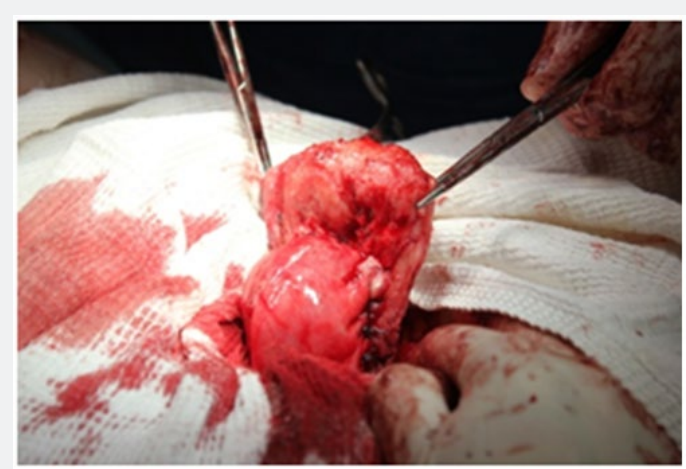

Figure 4: Closure of the flaps of the uterine wall approximating the myometrium and serosa of the one side of the bisected uterus in the anteroposterior plane with interrupted 2-0 Vicryl, while the contralateral side of the uterine wall is brought over the reconstructed first side in such a way as to cover it.

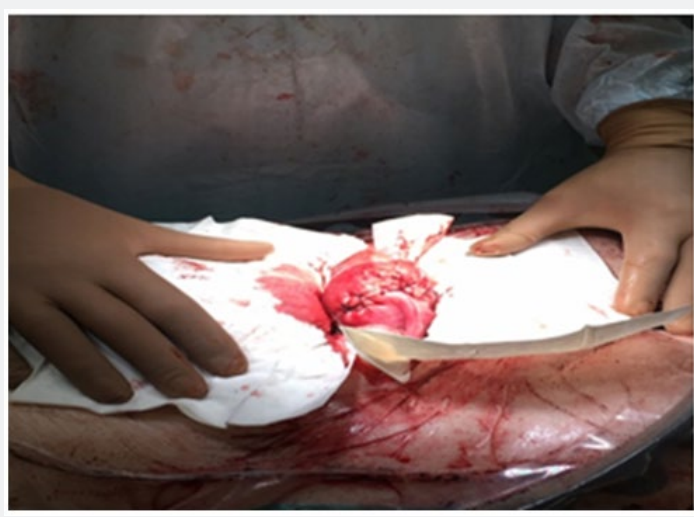

Figure 5: Final results of operation- uterus image. 


\section{Global Journal of Reproductive Medicine}

During the operation it was seen that in 12 patients the size of the uterus fitted 12 to 14 weeks of pregnancy, in 13 patients- 15 to 18 weeks and in 1 patient-up to 20 weeks. The average duration of surgery was $156.8 \pm 52.2$ minutes. The average blood loss during the operation amounted to $512.9 \pm 219.4 \mathrm{ml}$. Tissue removed during surgery of the uterus affected by adenomyosis, averaged $416.6 \pm 254.1$ gram. Simultaneously with hormonal treatment from the first days of the postoperative period all the patients were subjected to epigenetic therapy for 12-months. With the purpose to increase the efficiency of surgical treatment and prevent disease recurrence in the postoperative period, we developed hormonal therapy protocol: gonadotropin-releasing hormone agonist for 4-6 months-Dienogest for 6 months combined hormonal contraceptives (COCs) in continuous mode for 6 months or more. There was a strong reduction in both dysmenorrhoea and hypermenorrhoea and all patients returned to having normal menstrual cycles. Up to now 3 of the patients got spontaneously pregnant and delivered healthy kids and (Table 1). For the follow-up period recurrence of adenomyosis symptoms in all 26 cases were not seen. There were no recurrences before the 36-month follow-up visit. We questioned the women about their life quality before and after operation. Most of them answered-«very satisfied», no one was «dissatisfied» (Table 2) [11].

Table 1: Outcomes of adenomyomectomy with a triple-flap method as an infertility treatment (October 2012 - March 2018).

\begin{tabular}{|c|c|}
\hline Parameter & Study Data \\
\hline Patients & 26 \\
\hline Age (years) & $35.3 \pm 7.2(22$ to 47$)$ \\
\hline Patients wishing to conceive & $18 / 26(69,2)$ \\
\hline Pregnancies & $3 / 18(61.5)$ \\
\hline Spontaneous & 3 \\
\hline IVF & - \\
\hline Elective Caesarean section & 3 \\
\hline
\end{tabular}

Table 2: Satisfaction of women treated with combined surgicalmedical therapy during follow-up.

\begin{tabular}{|c|c|c|c|}
\hline & Very Satisfied & Satisfied & Dissatisfied \\
\hline $\begin{array}{c}\text { At the end of } \\
\text { the first year }\end{array}$ & $17(100)$ & $0(0.0)$ & $0(0.0)$ \\
\hline $\begin{array}{c}\text { At the end of } \\
\text { the second year }\end{array}$ & $8(88.9)$ & $1(11.1)$ & $0(0.0)$ \\
\hline $\begin{array}{c}\text { At the end of } \\
\text { the third year }\end{array}$ & $4(80)$ & $1(20)$ & $0(0.0)$ \\
\hline
\end{tabular}

\section{Discussion}

Treatment options for women with adenomyosis are diverse and consist of analgesic therapies, hormonal therapies, conservative or minimal invasive surgery, assisted reproduction technologies, or of a combination of these methods of adenomyosis treatment [12]. Treatment has to be customized to the individual needs of the patient $[13,14]$. Moreover, endometriosis has been shown to be a disease that cannot be cured easily and therefore can be regarded as a chronic disease in many women [15-17]. The surgical approach for preserving the uterus has become more popular, partly because some patients want to preserve their future fertility, and their dysmenorrhea does not respond to drug treatment $[5,8,10,11]$. In our view, surgical triple-flap method of adenomyosis for the patients with diffuse adenomyosisis currently is the best one, especially targeted for infertile women, wishing to conceive. Most of the women in our study wanted to get pregnant, that was the major reason for organ- preserving operation. Before considering the benefits of conservative surgery in the management of these sub fertile women with adenomyosis, we could not overlook the age factor, because it might be the most critical factor of fertility. It is well known that fertility declines after 35 years of age [18]. Our 3 patients who underwent this type of surgery and had subsequent course of hormone therapy got spontaneously pregnant. They were at the age of 28, 30 and 31 - as an argument in favor of the early age factor.

\section{Conclusion}

Thus, our experience of intraoperative radical resection of adenomyotic tissues suggests that this technique may be a surgery of the patient's choice, especially for women of reproductive age with diffuse adenomyosis, for those who have not realized their fertility yet. Also, this type of surgery may be recommended for a patient of late reproductive age, when hysterectomy is not their preference. Our results indicate that conservative surgery combined with hormone therapy in the treatment of massive diffuse forms of adenomyosis is effective in relief of symptoms, results in a high satisfaction rate among patients and a high success rate for preservation of the uterus for at least 5 years.

\section{References}

1. Barrier BF, Malinowski MJ, Dick EJ, Hubbard GB, Bates GW (2004) Adenomyosis in the baboon is associated with primary infertility. Fertil Steril 82(Suppl 3): 1091-1094.

2. Benagiano G, Habiba M, Brosens I (2012) The pathophysiology of uterine adenomyosis: an update. Fertil Steril 98: 572-579.

3. Levgur M (2007) Diagnosis of adenomyosis: a review. J Reprod Med 52(3): 177-193.

4. Bird CC, McElin TW, Manalo-Eslrella P (1972) The elusive adenomyosis of the uterus. Am J Obstet Gynecol 112(5): 583-593.

5. Huang BS, Seow KM, Tsui KH, Huang CY, Lu YF, et al. (2012) Fertility outcome of infertile women with adenomyosis treated with the combination of a conservative microsurgical technique and $\mathrm{GnRH}$ agonist: long-term follow-up in a series of nine patients. Taiwan J Obstet Gynecol 51(2): 212-216.

6. Wang PH, Yang TS, Lee WL, Chao HT, Chang SP, et al. (2000) Treatment of infertile women with adenomyosis with a conservative microsurgical technique and a gonadotropin-releasing hormone agonist. Fertil Steril 73(5): 1061-1062.

7. Wang PH, Liu WM, Fuh JL, Cheng MH, Chao HT (2009) Comparison of surgery alone and combined surgical-medical treatment in the 
management of symptomatic uterine adenomyoma. Fertil Steril 92(3): 876-885.

8. Wood C (1998) Surgical and medical treatment of adenomyosis. Hum Reprod Update 4(4): 323-336.

9. Grimbizis GF, Mikos T, Tarlatzis B (2014) Uterus-sparing operative treatment for adenomyosis. Fertil Steril 101(2): 472-487.

10. Osada H, Silber S, Kakinuma T, Nagaishi M, Kato K, et al. (2011) Surgical procedure to conserve the uterus for future pregnancy in patients suffering from massive adenomyosis. Reprod Biomed Online 22(1) 94-99.

11. Tskhay VB, Tsygankova NY (2016) Modern methods of surgical treatment of severe adenomyosis. Siberian medical review (Rus) 98(2): 22-31.

12. De Graaff AA, Dirksen CD, Simoens S, De Bie B, Hummelshoj L, et al (2015) Quality of life outcomes in women with endometriosis are highly influenced by recruitment strategies. Hum Reprod 30(6): 13311341 .

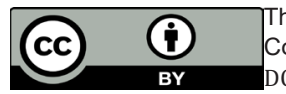

is work is licensed under Creative ommons Attribution 4.0 License

DOI: 10.19080/GJORM.2018.04.555650
13. Kennedy S (1991) What is important to the patient with endometriosis? Br J Clin Pract Suppl 72: 8-13.

14. Dancet EA, Ameye L, Sermeus W, Welkenhuysen M, Nelen WL, et al. (2011) The ENDOCARE questionnaire (ECQ): a valid and reliable instrument to measure the patient-centeredness of endometriosis care in Europe. Hum Reprod 26: 2988-2999.

15. Guo SW (2009) Recurrence of endometriosis and its control. Hum Reprod Update 15(4): 441-461.

16. Vercellini P, Crosignani PG, Abbiati A, Somigliana E, Viganò $\mathrm{P}$, et al (2009)The effect of surgery for symptomatic endometriosis: the other side of the story. Hum Reprod Update 15(2): 177-188.

17. Berlanda N, Vercellini P, Fedele L (2010) The outcomes of repeat surgery for recurrent symptomatic endometriosis. Curr Opin Obstet Gynecol 22(4): 320-325.

18. Templeman C, Marshall SF, Ursin G, Horn-Ross PL, Clarke CA, et al. (2008) Adenomyosis and endometriosis in the California Teachers Study. Fertil Steril 90(2): 415-424.

\section{Your next submission with Juniper Publishers will reach you the below assets}

- Quality Editorial service

- Swift Peer Review

- Reprints availability

- E-prints Service

- Manuscript Podcast for convenient understanding

- Global attainment for your research

- Manuscript accessibility in different formats

( Pdf, E-pub, Full Text, Audio)

- Unceasing customer service

Track the below URL for one-step submission https://juniperpublishers.com/online-submission.php 